\title{
Issues of Criminal Procedures Relating the Juvenile Freedom Deprivation
}

\author{
Prof. As. Dr. Jola Xhafo (Bode) \\ Criminal Law Department, Law Faculty, University of Tirana, Albania \\ xhafojola@yahoo.com
}

\section{Doi:10.5901/mjss.2015.v6n2s5p199}

\begin{abstract}
Freedom is one of the fundamental rights sanctioned in a number of international human rights acts when the European Convention on Human Rights is the main framework. Freedom is considered a fundamental right and is guaranteed also in the Albanian Constitution. Being a fundamental right it can be limited any by law. In order to prevent the arbitrary violation of this right, the article 27 of Constitution determines limited cases of freedom deprivation. The article 28 of the Constitution, also foresees some guaranties and rights for persons deprived from liberty. These rights and guaranties are completed in specifies laws when the Criminal Procedure Cod is a crucial one. The Criminal Procedure Cod provide also special rules to safeguard the rights and the interest of juveniles throughout the deprivation of liberty preceding. However in the justice organs practice still there are problems in fully implementing these rights. The article will address issues related the criminal procedure and the legal guaranties related the deprivation of liberty based on the national legislation and international standards. The paper will focus mainly on the special standards relating the protection of juveniles taking in consideration the special needs of this group. In the framework of Procedural Criminal Code rules, international juridical acts and the court practice, concrete conclusions will be drawing in regard to the actual situation related with the respect of the juvenile rights on this stage of proceeding. Considering the current situation, recommendations will be displayed relating the legal and institutional improvements are needed in order to comply with international standards on children's rights.
\end{abstract}

Keywords: Criminal, Procedure, Cod, Freedom, deprivation, International, juridical, acts, Procedural, measure.

\section{The Right to Freedom and Security as Part of the Notion of Fundamental Rights}

The right to freedom and security is one of the fundamental rights of persons. In terms of constitutional rights, freedom is one of the most essential aspects. Bringing this right to a constitutional level has now become a general rule for all democratic countries. Sanctioning this principle, in addition to other principles regarding fundamental rights and freedoms, at constitutional level, serves as a safeguard for respecting and implementing these principles.

Nevertheless, even this right is not absolute. To guarantee the arbitrary infringement of this right, the Constitution of the Republic of Albania (AR Constitution) specifies the cases of freedom deprivation and sets forth a number of minimal safeguards for the person's deprivation of freedom. It sets forth a number of procedural safeguards to the person deprived of freedom for one of the reasons stipulated by the law.

The Constitution stipulates that every person deprived of freedom enjoys the following rights: the right to notification of the causes for the measure or the relevant charge, the right to a lawyer, the right to complaint, the right to be heard before trial etc. ${ }^{1}$ Moreover, the Constitution expresses some of the fundamental principles of the criminal process, which serve as a greater guarantee for the person under deprivation of freedom. Here are a number of principles: Habeas Corpus (Article $28 / 3$ of the Constitution), the principle of not applying the criminal law with retrospective power, (Article 29), the principle of presumption of innocence (Article 30), the ne bis in dem principle, (Article 34) etc.

The constitution elaborates on a number of the most fundamental elements of the criminal process and the safeguards to the person deprived of freedom, followed by a more detailed elaboration in special laws. The main laws are the Criminal Code and Code of Criminal Procedure (CPC).

This constitutional regulation is in compliance with the aim of the European Convention on Human Rights (ECHR), ratified by Albania. This is the only international agreement equal with the constitution in terms of hierarchy.

Article 5 of the European Convention on Human Rights also provides for the right to freedom and security and the possibility of limiting this right solely for cases expressly stated.

\footnotetext{
${ }^{1}$ Constitution of the Republic of Albania, Article 28.
} 
The ECHR also provides a number of fundamental safeguards to persons under conditions of personal freedom deprivation. Article $5 / 2$ sets forth the right of each person to be informed in the shortest time possible, in the language he/she can understand, about the reasons of the measure or any charges against him/her. Article $5 / 3$ refers to the right of the person to be sent to the judge within a reasonable deadline, otherwise known as the Habeas Corpus principle. Article $5 / 4$ sets forth the right of each person deprived of freedom to complain before a court regarding the measures taken by him. Moreover, Article 5/5 grants him/her the right to a fair compensation in cases of illegal arrest or imprisonment.

Being an important document in the field of human rights, it acts as an international safeguard by setting a minimal standard for these rights and is regarded as a roadmap of domestic legislations in this field. The extensive practice of ECHR has made an extraordinary interpretation of cases of person's deprivation of freedom, as well as rights of persons under the conditions of personal freedom deprivation, thus becoming a very good example for domestic courts of countries which have ratified ECHR.

However, there have also been cases of violation and non-implementation of this principle, resulting in serious consequences regarding the respect of fundamental rights and freedoms of citizens. This phenomenon becomes more concerning if there is a violation of procedural safeguards applicable to juveniles deprived of freedom.

\section{Sanctioning Procedural Safeguards in the Domestic Legislation}

Article 27 of the Constitution established that:

"No one's liberty may be limited, except in cases and under procedures prescribed by law". In accordance with this constitutional requirement, rules and procedures of constraint are detailed in CPC. Typical cases of freedom deprivation are the cases relating to arrests and detention of suspects for committing a crime and the application of security measures.

More specifically, the arrest and detention are provided in Chapter III of title V of the CPC, articles 251-259. This chapter contains general procedural aspects of the terms and implementation procedures of arrest and detention, which apply in general, without excluding any particular category, including juveniles. Arrest in flagrancy is performed when flagrant conditions exist and comply with criteria set out in article 251, while the ban applies in cases of risk of escape of the person suspected of committing a crime18. CPC has not sanctioned any exception regarding the conditions of the implementation of arrest in flagrancy and detention. With the amendments of 2002 it was provided that juvenile offenders accused of a misdemeanor may not be detained prior to trial2.

As regards security measures, Article 228 specified the general conditions for setting security measures; reasonable doubt based on evidence, the existence of penalty causes and the existence of the criminal offence. The following special conditions are also specified: the existence of important causes which jeopardize the acquisition or veracity of the evidence, escape of the defendant or risk of escape, the risk that the defendant may commit serious crimes or crimes of the type he is being tried. The following dispositions also specify the criteria for setting security measures, the conditions for revoking or removing them, their duration, replacement, or the right to complain about the security measures.

In compliance with the Constitution and international juridical acts, a number of procedural measures have been foreseen to ensure that the person's deprivation of freedom be done in conformity with the dispositions of the material and procedural law, under the principle of legality as one of the fundamental principles of any democratic legal order.

The proper implementation of material and procedural dispositions provide the subject with the execution of all rights and safeguards stipulated by the law under a regular legal process. The right of the person deprived of freedom to have a lawyer, no matter whether he/she has been made a defendant (article 48), as well as the right to have the necessary time and facilities to prepare the defense, must be a real and effective possibility. Moreover, the person deprived of freedom enjoys the right to information about the reasons for his detention or arrest. He has the right to be informed not make any statements because everything he says may be used against him at trial. The person detained or arrested in flagrante enjoys the right to be sent before a judge within 48 hours and it is the judge who decides whether the measure is legal. This obligation derives from the famous principle Habeas Corpus. This principle, first set forth in Magna Carta, is a fundamental safeguard to the detainee. The person deprived of freedom is entitled to communicate with his lawyer at any moment. Cases of obligatory presence of the lawyer are set forth, such as meetings, examinations, questioning of the defendant, etc.

As regards pre-trial detention, being the harshest measure, Article 230/1 specifies that the criterion for the

${ }^{2}$ CPC, article 230/4. 
application of prison arrest is when all other measures are not relevant. A special procedural safeguard in this case is the exclusion of a number of specific subjects from the application of the pre-trial detention security measure. Article 230 of the Code of Criminal Procedure exempts the following subjects from pre-trial detention: pregnant or breastfeeding women, persons of grave health conditions or over 70 years old, drug-addicted or persons under the effects of alcohol. This is an application of the principle of proportionality, with the lawmaker exempting these subjects for the specific features they have.

A number of other principles pertaining to an appropriate legal process, such as the principle of the presumption of innocence, the right not to incriminate oneself, the right to silence, guarantee the person the protection of his rights in the legal process. Another very important safeguard is the one set forth in Article 5 of the Code of Criminal Procedure, which states as follows: No one can be subjected to torture, cruel, inhuman or humiliating treatment or punishment and persons sentenced to imprisonment are provided with human treatment and moral rehabilitation. This is an absolute prohibition, which cannot be used even in the most extreme circumstances.

What is of great importance to the practice of justice authorities is that they be applied correctly, thus providing the person with the right to a correct legal process, in pursuance of Article 42 of the Constitution and Article 6 of ECHR.

\section{Special Procedural Measures for Juveniles}

The safeguards set forth by the Code of Criminal Procedure for persons deprived of freedom are applicable both to adults and juveniles. However, due to the special nature and level of development, juveniles deprived of freedom enjoy a number of procedural safeguards. These safeguards are sanctioned in the international juridical acts of justice on juveniles, which specify the standards of juvenile treatment at this stage of the procedure. These standards should be reflected in the domestic procedural legislation and should be implemented by justice authorities.

These standards are particularly important in cases relating to deprivation of personal freedom and the application of security measures which represent the first contact of juveniles with criminal justice. For this reason, in case of juveniles, will be of great interest to focus on the analysis of these specific procedural guaranties and the problematic issues related to their application.

\subsection{The principle of the best interests of the child}

The principle of the best interests of the child is the main consideration against all action taken against children ${ }^{3}$. It is sanctioned in almost all international juridical acts such as the Beijing Rules, Riyadh's Directives, Havana Rules etc.

Doctrinal studies consider it a principle overlapping with the rights guaranteed for every individual and applied only to a category of subjects, who receive state protection due to juvenile age. ${ }^{4}$ It asks each country which has approved the convention to adopt the legislation which must reflect this principle in each aspect of justice for juveniles.

The principle of the best interests of the child should dominate decision-making regarding every procedure applied to children. The best interest of the child should also be the leading consideration in all criminal procedures and implementation of state mechanisms to juveniles accused or suspected of criminal offences.

Obviously, it is not easy to determine the necessary measures of this principle in practice. The practical implementation requires that this principle be closely connected with all other rights and safeguards provided for juveniles by international juridical acts, and it requires the obligation to respect these rights.

As regards the treatment of juvenile offenders, special attention should be paid to this principle, in particular in cases of limitation or deprivation of freedom, especially the application of detention or any other procedure of freedom deprivation where the best interest of the child should prevail. This rule requires the establishment of the legal status of the juvenile and the need of differentiation in terms of rights enjoyed by juveniles depending on their age. For example, juveniles who have not reached the age of criminal liability cannot be subjected to measures involving deprivation of freedom or criminal sanctions. As regards juveniles at the age of criminal liability, the application of these measures should be used as an exclusive case and last for the shortest time possible.

\footnotetext{
3 With regard to this principle, the UN Convention "On the rights of the child", Article 3 states:

"In all actions concerning children, whether undertaken by public or private social welfare institutions, courts of law, administrative authorities or legislative bodies, the best interests of the child shall be a primary consideration."

${ }^{4}$ Albanian legislation and the convention of the rights of the child, publication of the Centre of Services and Integrated Legal Practice, 2008, p. 51.
} 


\subsection{Deprivation of freedom as the last resort}

The principle of deprivation of freedom, only in cases in compliance with legal procedures, is now a universal principle. As regards juveniles, in compliance with the best interest of the child and the need for special treatment, the leading principle is the one which states that: Measures of freedom deprivation should be taken as a last resort and the shortest time possible.

This principle exists in almost all recently sanctioned legal acts of juvenile justice, starting from the UN Convention ${ }^{5}$. Also, in accordance with the Rule 17.1 (c) of the Beijing Rules, deprivation of freedom for minors should be an exceptional case which should be applied only in specific cases ${ }^{6}$. The same adjustments can also be found in the United Nations Rules, for the protection of juveniles deprived of freedom, where freedom limitation happens only in exceptional cases ${ }^{7}$. This principle enshrined also in other instruments such as Rule 46 of the Riyadh Guidelines, Rule 17 of Rules of Havana, etc.

According to international standards, in the CPC this rule should be extended to all cases relating to detention and arrest of juveniles and alternative measures to detention or arrest should be provide. International instruments have provided the procedural solution in favor of the application of freedom deprivation as a last resort, where is worth mentioning the increase of the self-determination right of the police and prosecution in order to avoid the formal procedures ${ }^{8}$. For this purpose it is suggested the creation of community programs such as temporary supervision and protection, restitution and compensation of victims ${ }^{9}$. The CPC has not forecasted the principle that children shall only be deprived of liberty as a last resort, and for the shortest appropriate period of time. Also the specific criteria applying for juveniles, does not make possible the application of this principle.

For example, regarding the pre-trial detention measure as the most severe measure CPC has sanctioned the principle that it should be applied, only when every other measure is inappropriate due to the high risk of crime and the offender ${ }^{10}$. Simultaneously for certain groups such as pregnant women or nursing mothers, persons in serious health condition or who have attained the age of 70 years, or drugged or alcoholic people who are subject of therapeutic programs in special institutions, these measure can be imposed only in exceptional cases. This rule does not apply for juveniles.

The only special requirement of the implementation of this measure to juvenile, is that it cannot be determined for juveniles accused of a misdemeanor ${ }^{11}$. Pursuant to this measure, the court must take into consideration the continuity of the educational process of juveniles.

The above criteria are insufficient. In this way the legislator has not taken into account the requirements of international legal acts that stipulate the principle that pre-trial detention should be a last measure to be applied to juveniles.

Despite the legal determination that this pre-trial measure should be used when all other measures are inadequate, in the absence of specific criteria, this measure has been applied frequently to the juveniles.

Also, court decisions have not always been reasonable in terms of applying this measure in cases of juveniles. These shortcoming is evident in several cases of the Supreme Court, which in a majority of cases has changed the court decisions regarding the pre-trial detention measure at juvenile offenders ${ }^{12}$. Essential arguments of Supreme Court decisions are based on the fact that the district court did not properly evaluate the criteria for determining this security measure.

Consequently the courts do not in any case take into consideration the standard of deprivation of liberty as a last resort. Simultaneously with all the positive changes made as a result of the transfer of the detention system, from the Ministry of Interior to the Ministry of Justice still there are also problems with implementing the pre-trial detention measure and the institutional infrastructure.

\footnotetext{
${ }^{5}$ Article 37/b of Children Rights Convention provides that any deprivation of liberty must be: legal and not arbitrary; be imposed as a last resort for solutions; extended only for the shortest period of time as possible.

${ }^{6}$ Rule 17.1 (c) of the Beijing Rules provides that: "Deprivation of freedom shall not be appointed until the juvenile be convicted of a serious act involving violence against another person, or repetition in the performance of other serious violations, in cases when there is no other suitable reaction"

7 United Nations Rules for the protection of juveniles deprived of liberty, rule 2 and rule 17.

${ }^{8}$ Beijing Rules, rule 11.3.

$9 \mathrm{lbid}$, rule 11.4

10 CCP, article $230 / 1$.

${ }^{11} \mathrm{CPC}$, Article $230 / 4$.

12 See Decision of the Supreme Court, no 00-2008-36 date 05.03.2008, decision no51, date 25.02.2009 etc.
} 
The sections of the pre-trial-detention sections were the juveniles are cept do not fully comply with the standards and the needs of their treatment and education. In the new legislative changes priority should be given to provisions that provide the possibility of applying the freedom deprivation as a last resort or provisions that provide alternative measures from the restriction of freedom.

\subsection{The right to defense}

The right to defense is sanctioned in the Constitution of the Republic of Albania as one of the safeguards in the criminal process. The constitution sanctions not only the right to a lawyer and free communication with him but also the obligation of the state to provide free protection ${ }^{13}$.

To make it practically applicable, the right to defense has been detailed in the CCP, which includes detailed rules regarding legal defense at all stages of the process. Predictions concerning the execution of the right of defense are available for both the juvenile and adult offender. In addition, taking into account the significance of the criminal prosecution of a juvenile, the CPC includes also a number of specific provisions.

In relation to minors under 18 years $\mathrm{CPC}$ has sanctioned the principle of legal defense in every condition and degree of processing and the binding character of this right ${ }^{14}$. The interrogation of the juvenile arrested or detained should be done in the presence of a lawyer chosen or assigned ${ }^{15}$. In the case of juvenile offender legal defense is an essential condition for the validity of the criminal proceedings.

\subsection{Psychological assistance}

The right to defense is insufficient to meet the best interests of children deprived of freedom unless psychological assistance is provided. This attitude is also reflected in the Convention on the rights of the child, which provides not only the right to legal defense but also any other relevant assistance when deemed to be in the best interest of the child, in the presence of parents or his legal representatives ${ }^{16}$. With the same way of formulation, this principle has been also set forth in rule 15/2 of the Beijing Rules. In the comments about rule 15/2 of the Beijing Rules, the right of the parent or caretaker to attend the procedure is considered as emotional and psychological assistance and it lasts for the whole procedure. ${ }^{17}$

Psychological assistance is one of the special procedural guarantees that CPC has sanctioned for the juvenile offender. This assistance is provided in every state and stage of the proceedings with the presence of a parent or other persons chosen by the minor and accepted by the proceeding authority. When the defendant is a juvenile proceeding authority may take actions and may not engage in acts without the presence of a parent or other person chosen by the minor ${ }^{18}$. Deviations from this principle can only be made when it considered that is in the interest of juveniles or the delay could seriously damage the prosecution. In such cases it is obligatory presence of counsel.

Besides the presence of parents or other relatives in the criminal prosecution of juveniles, a special importance takes the psycho-social assistance in the presence of a psychologist or social worker, who has the necessary skills and creates appropriate conditions that the juvenile can psychologically afford the process.

The psychologist also attends cases when a juvenile is interrogated by police or prosecution authorities. In this way, the role of the psychologist acts as support to the juvenile, thus facilitating communication with the relevant authorities.

As regards the sanctioning of psychological assistance in the criminal procedure against juveniles, a number of deficiencies have been observed despite the initial positive changes in the legal practice. The analysis of judicial decisions concerning measures has shown that, in some cases, psychological assistance to juveniles has not been provided. ${ }^{19}$ Over the last years, progress has been made in providing this service. In some criminal justice bodies, such as the police or prosecution, the psychologist is an integral part of the personnel. Nevertheless, there is not a final solution about the role of the psychologist and clear recruitment criteria.

${ }^{13}$ Constitution of the Republic of Albania, Article 31, point $b$ and ç.

${ }^{14} \mathrm{CPC}$, article 49/2.

${ }^{15} \mathrm{CPC}$, article 256/1.

${ }^{16}$ Convention on the rights of the child, Article 4/b(iii).

17 OSBE, Juvenile justice training project, Tiranë 2005, f. 3.

${ }^{18} \mathrm{CPC}$, article 35.

${ }^{19}$ Albanian Helsinki Commitee, Observance of the Rights of Juvenile Offenders in Criminal Proceedings, (2007) PEGI, Tirana p. 20. 


\subsection{Specialized structures}

A particular importance in the phase of freedom deprivation takes the demand of international standards regarding the treatment of minors by specialized structures. The Beijing Rules lay down an obligation that the police structures that deal with minors should be instructed and trained in particular. For this purpose in larger cities special police forces should be formed ${ }^{20}$. Committee on the Rights of the Child considers as a priority issue the need to train police officers in order to ensure that children be treated carefully and their rights are respected, and parents be informed immediately after arrest and the guarantee of legal assistance 21 .

In the framework of these requests since 2008 a new structure of the State Police is created, that of protection of minors and fighting the domestic violence. In the General Police Directorate this sector is an integral part of the Department of investigation and prevention of crimes. Such coordination structures are set up even in country's districts.

However, the priority of treatment of juveniles by specialized structures has not yet found adequate application in practice. Treatment of juveniles in the early stages of procedures, detention or arrest are, made from structures of the police forces who do not always have the necessary skills and specialization on the rights of juveniles. In addition, in practice there were cases of non-compliance of the procedural safeguards during interrogation of juveniles after arrest or detention 22 .

With the amendments of the CPC, is sanctioned the standard of specialized structures for the adjudication of juveniles. Currently the trial of juveniles is done by the relevant sections, created in the judicial district courts established by Decree of the President. The creation of these courts as well as conditions imposed on the CPC for the trial of minors by judges specialized in this field, serves to the knowledge of the procedural provisions for juveniles and their correct application. Now these specialized structures are not only competent for the trial of minors but also to any other decision stages of criminal proceedings including the implementation of security measures.

However, there are still problems with the operation of specialized structures at judgment level. For a number of high risk crimes, juveniles are tried by the Court of Serious Crimes, which lacks specialized sections for juveniles. Another deficiency which needs to be overcome is the absence of specialized sections for juveniles at Appeal Courts ${ }^{23}$.

\section{Conclusions}

Both domestic and international laws explicitly set forth cases of person's deprivation of freedom. This helps to avoid, as much as possible, the probability of arbitrary deprivation of this right. The person under personal freedom deprivation enjoys procedural safeguards and rights during the criminal process, which he is entitled to fully enjoy in accordance with the law. Implementation of such rights and the provision of the person with an effective possibility to enjoy them are being continuously consolidated in the Albanian legal system, thus implementing international agreements ratified by Albania, with the ECHR being a very important one. This Convention, along with other agreements ratified by Albania, constitutes another safeguard to respect the rights of the person deprived of freedom. Although the Albanian legislation provides protection of the person's rights in the criminal process, there are still a number of challenges to implement these rights not only by the lawmakers but by the authorities in charge of implementing the legislation in particular. In this respect, special attention should be paid to the legal sanctioning and the implementation of the rights of juveniles deprived of freedom.

For this purpose necessary legal changes should be made in order to determine appropriate alternative measures of freedom deprivation of liberty, and mainly of pre-trial detention measure to be applied in cases of juveniles. In this context changes also should be made to CPC regarding specific time periods of pre- trial detention for juveniles and specific criteria for applying this measure.

One of the shortcomings of the actual code is that no specific arrangements are sanctioned regarding the freedom deprivation of juveniles. In contrast, international legal acts on the rights of children, recommend that in accordance with the best interest of the child, priority should be given to the special treatment at all stages of the proceedings from the moment of detention of juveniles until the proper measure is taken.

Also in the CPC should be increased the number of principles of criminal proceedings related to minors. In this

20 Beijing Rules, rule 14.

${ }^{21}$ Comity of the rights of the children report, CRC/S/GC/10, item, 152(b)(ii).

${ }_{22}$ Albanian Helsinki Commitee, Respect for human rights in places of detention, (2007), Pegi, Tirana, pg. 36.

23 If we refer to foreign systems, we find examples of specialized structuresëse even at Courts of Appeal. For example, in Italy trial at the Court of Appeal for juveniles is carried out by the Juveniles Section of the Appeal Court. See CCP, Article 2. 
regard, the additions and changes that CPC will undergo should take into consideration the special coverage of the principles of criminal proceedings for juveniles.

These legal interventions are necessary considering that the practice has yet identified problems with the treatment of juveniles at the time of detention and arrest. These problems relate to inadequate infrastructure facilities of detention in police stations, as well as with the treatment and respect of their rights.

\section{References}

Albanian Helsinki Committee, Criminal justice system for juveniles in Albania, (2005) PEGI, Tirana; Albanian Helsinki Committee, Respect for human rights in places of detention, (2007) PEGI, Tirana; Albanian Helsinki Committee, Observance of the Rights of Juvenile Offenders in Criminal Proceedings, (2007) PEGI, Tirana; Islami. H, Hoxha. A, Panda. I; Commentary of the Criminal Procedure Code, (2007), Tirana, Center of services and integrated legal practices, Albanian legislation and the Convention of Children Rights, (2008), Tirana; O Donell. D, Assessment of Juvenile justice reform in Albania, (2009), UNICEF;

Constitution of the Republic of Albania adopted in November 1998;

Crimial Procedure Code, approved by Law no. 7905, dated 21. 3. 1995, amended

Decree no. 6218, 07. 07. 2009 "On establishment of penal sections of juveniles near the district courts";

UN Convention "On the Children Rights", 1989;

UN Convention "Against Torture and inhuman or degrading treatment", 1984;

Standard Minimum Rules of the United Nations for the administration of juvenile justice (The Beijing Rules) 1985;

United Nations Rules for the Protection of Juveniles Deprived of their Liberty (Havana Rules) 1990;

Standard Minimum Rules of the United Nations concerning the non-arrest measures (Tokyo Rules) 1990;

United Nations Guidelines on Prevention of Juvenile Delinquency (Riyadh Guidelines) 1990;

Standard Minimum Rules of the United Nations for the administration of juvenile justice (The Beijing Rules) 1985;

United Nations Rules for the Protection of Juveniles Deprived of their Liberty (Havana Rules) 1990;

Standard Minimum Rules of the United Nations concerning the non-arrest measures (Tokyo Rules) 1990;

United Nations Guidelines on Prevention of Juvenile Delinquency (Riyadh Guidelines) 1990;

Decision of Supreme Court No. 00-2009-36 (42), at 05. 03. 2008;

Decision of Supreme Court No. 51, dated 25. 02. 2009; 